\title{
Assessment of camel thorn (Alhagi maurorum) as new sources of bioactive compounds using GC-MS technique
}

\author{
Reham M. Mostafa, Heba S. Essawy* \\ Botany Department, Facukty of Science, Benha University, Egypt
}

Corresponding author: hebasamyessawy@live.com

\begin{abstract}
Alhagi maurorum (A. maurorum) is one of the medicinally important plants belonging to the family leguminasae, commonly known as camel thorn. This research was amid to identify the chemical compounds in the aerial part of $A$. maurorum using GC-mass analysis. Three solvents with different polarities were used for the extraction of chemical constituents (water, methanol and petroleum ether). The results of GC-MS analysis led to identification of various compounds. In total, thirty-nine compounds from petroleum ether extract, thirty-two compounds in methanolic extract and seventeen compounds in aqueous extract were identified. Majority of the identified compounds have been reported to possess many biological activities. Among them, we reported 10 new anticancer compounds (Vitamin E; Hexadecanoic acid; Stigmast-5-en-3-ol; Phytol,2-hexadecen-1-ol,3,7,11,15-tetramethyl; Squalene; Hexadecanoic acid; 2-hydroxy-1-(hydroxymethyl) ethyl ester; Oxime,methoxy-phenyl,methyl N-hydroxybenzenecarboximidoate; Ergost-5-en-3-ol; 9,12- Octadecad-ienoic acid and Farnesol) from A. maurorum using three solvent, while the best effective solvent was petroluem ether. Therefore, we report that $A$. maurorum has great potential to be developed into anticancer drugs.
\end{abstract}

Keywords: Secondary metabolites; Alhagi maurarum; GC-mass spectroscopy; anticancer compounds.

\section{Introduction}

Natural products have useful and interesting biological activities and they also do several functions. Researchers are progressively turning their attention toward natural products in order to develop better drugs against cancer as well as viral and microbial infections (Revathi and Parimelazhghan, 2010). In Egypt the medicinal plants represent a new promising resource, as there is a relatively high representation of medicinal species in the native flora. It is already seen the need to shed light on some medicinal plants because of their significance (Asmeda, 2013). Phytochemical studies on A. maurorum show carbohydrates, tannins, unsaturated sterols, triterpenes, flavonoids, and flavanone glycosides (Hamed et al., 2012).

Alhagi maurorum belongs to the Fabacea family and Fabales order. Fabacea comprises approximately 730 genera and 19,400 species. Plants belonging to this family are known to produce a large number of biologically important secondary metabolites. A. maurorum is one of the species of legumes. It is also known as camel thorn, Caspian manna, or Persian manna-plant (Duke, 2007). A. maurorum plant is extensively distributed and has wide ecological amplitude. It recorded from Nile region, oasis, Mediterranean region, Eastern and Western Desert, Red sea Coast and Sinai, also in Saudi Arabia deserts (Hassanein and Mazen, 2010). Alhagi maurorum is a very common woody perennial shrub, rich in flavonoid and phenolic compounds with more than twelve different isolated flavonoids (Al-Jaber et al., 2011). It is being used in diuretic, diaphoretic, and anti-ulcer treatments, and also has tissue-repairing properties (Al-Snafi, 2015). The plant is used in the treatment of diseases of the liver and urinary tract, and also as a laxative (Marashdah and Al-Hazimi 2010). The oil extracted from the leaves is applicable for the treatment of rheumatism, and the flowers are used for warts and migraines (Awaad et al., 2011). A study by Sulaiman showed that this plant has anti-bacterial properties (Sulaiman, 2013). In vitro anticancer activity of Ocimum Basilicum, Alhagi maurorum, Calendula Officinalis and their Parasite Cuscuta Campestris were studied by (Behbahani, 2014).

\section{Results and Discussion}

Results of GC-MS analysis in our study led to identification of various compounds, in the aerial part of $A$. maurorum using three different solvents and these compounds shown anticancer and cytotoxic properties. Thirty-nine compounds from petroleum ether extract (Table 1; Fig 1), thirty-two compounds from methanolic extract (Table 2; Fig 2) and seventeen compounds from aqueous extract (Table 3; Fig 3) were identified. The present study revealed that $A$. maurarum have fatty acids, phenols, steroids, alkanes, vitamine $\mathrm{E}$ and terpenoids as stated by (Ahmad et al., 2015). The chemical investigation of the Alhagi species by Karuppasamy et al. (2012), Kalhoro et al. (1997) and Verma et al. (2013) revealed the presence of many contents such as sterols, fatty acids and flavonoids (Behari and Gupt, 1980) and (Awaad et al., 2011) coumarins and alkaloids. Phenolic 
compounds are considered as the biggest and widely dispersed groups of secondary metabolites in plants (Scalbert and Williamson, 2000).

Total phenolic and flavonoids contents of $A$. maurorum showed high concentrations, especially in the methanol extract.

Most of the identified compounds have been reported to possess interesting biological activities as antimicrobial, antiviral, antioxidant, anticancer, antitumor and antiinflammatory e.g. phenol, 4- (methoxymethyl); stigmasterol; 2H-1-benzopyran-7-ol,3-(2,4-dimethoxyphenyl) -3,4-dihydro; 2-furan- carboxaldehyde,5-(hydroxymethyl); tetradecanoic acid, methyl ester; dodecanoic acid;; cosane derivatives; naphalene derivatives; Erythritol; Bis (2-ethylhexyl) phthalatehalic acid; Loliolide; Ledol (Shubhangi, 2016; Himaja and Moonjit, 2014; De Oliveira et al., 2014; Kuppuswamy et al., 2013). In this study, we identified ten new anticancer bioactive compounds in $A$. maurorum in Egypt, including Hexadecanoic acid; Stigmast-5-en-3-ol; Phytol,2-hexadecen-1-ol, 3,7,11,15-tetramethyl; vitamin E; Ergost-5-en-3-ol; Farnesol; Squalene; Hexadecanoic acid, 2hydroxy-1-(hydroxymethyl)ethyl ester; 9,12-Octadecadienoic acid and Oxime-,methoxy-phenyl,methyl N-hydroxybenzenecarboximidoate (Table 4).

Using GC MS method, Sianipar et al. (2016) recorded only four anticancer compounds such as Hexadecanoic acid, Stigmast-5-en-3-ol, Ergost-5-en-3-ol and Farnesol) in the leaves and tubers of the fourth generation of rodent tuber's (Typhonium flagelliformeLodd.) vegetative mutant clones (MV4). In this study, Hexadecanoic acid was a solitary compound that appeared with the three solvent. Hexadecanoic acid (palmitic acid) was selectively cytotoxic against leukemia cancer cells MOLT- 4 due to its interaction with DNA topoisomerase I and its ability to induce apoptosis. Hexadecanoic acid had in vivo antitumor activity (Harada et al., 2002). Biological activities of hexadecanoic acid ethyl ester were antioxidant, antimicrobial (Bodoprost and Rosemeyer, 2007) which could reduce the risk of coronary heart disease. Hexadecanoic acid methyl ester was able to inhibit the growth and induce apoptosis of human gastric cancer cells (Yu et al., 2005). Hema et al. (2011); Pietro et al. (2010) and Hsouna et al. (2011) showed another activities as hypocholesterolemic, nematicide, anti-androgenic flavour, haemolytic, 5-Alpha reductase inhibitor, potent antimicrobial agent, antimalarial and antifungal. The n-hexadecanoic acid has been recognised as the major compound in the leaves of Cleistanthus collinus (Parasuraman et al., 2009). Siddiq Ibraham et al. (2009) recorded the presence of $n$ Hexadecanoic acid in ethyl acetate extract of Goniothalamus umbrosus using GC-MS analysis. Stigmast-5-en-3-ol is a phytosterol with various biological activities. It could reduce the cell's cholesterol level and modify membrane lipid profile (Awad et al., 1996). This is an antidiabetic compound (Sujatha et al., 2010), which is able to inhibit the growth of cancer cells such as lung (Mendilaharsu et al., 1998), gastric (De Stefani et al., 2000), and ovary (McCann et al., 2003) cancers. It also has anti-tumor activity (Ekade and Manik, 2014), antioxidant (Zawistowaski, 2010), anti-osteoarthitic (Gabay et al., 2010), cyto-toxicity activity (Huang et al., 2009) and antiHIV reverse transcriptase (De Oliveira et al., 2014). Ergost-5en-3-ol (campesterol) is a phytosterol which has been proven to be able to inhibit various cancer cells, such as lung (Mendilaharsu et al., 1998), gastric (De Stefani et al., 2000), and ovary (McCann et al., 2003) cancers. Farnesol is a nonsterol isoprenoid which is commonly found in various fruits and aromatic plants, such as citrus, sage, spearmint, nutmeg, basil, lemon grass, and chamomile. Farnesol could selectively inhibit the proliferation and induce apoptosis of leukemia and cervical cancer cells (Rioja et al., 2000; Yazlovitskaya and Melnykovych, 1995). Farnesol has in vivo antitumor and anticarcinogenic activities (Belanger, 1998); (Crowell, 1999). Farnesol is shown to have detrimental effects on many microbes including bacteria and other fungi, such as Staphylococcus aureus, Saccharomyces cerevisiae, Aspergillus species, Paracoccidioides brasiliensis and Mycobacterium smegmatis (Semighini et al., 2006; Jabra-Rizk et al., 2006).

Squalene was able to inhibit carcinogenesis of various cancer cells, such as colon cancer (Rao et al., 1998). Samejo et al. (2012) extracted squalene from the leaves of $A$. maurorum in Iraq. Squalene is being used in cosmetic products as a natural moisturizer (Sermakkani and Thangapandian, 2012). Vitamin $\mathrm{E}$ ( $\alpha$ dan $\gamma$-tocopherol) has been proven to be able to reduce the risk of carcinogenesis (Jiang et al., 2001). Squalene has been reported in Aloe vera (Arunkumar and Muthuselvam, 2009) and (Praveen Kumar et al., 2010). The 9,12-Octadecadienoic acid (Z, Z) was found to have potential cancer preventive, anti-inflammatory and antiarthritic activities. Similar result was reported in Croton tiglium seed and found to have potential antioxidant and anticancer activity (Mangunwidjaja et al., 2006). Devi et al. (2009) reported that Euphorbia longan leaves mainly contains 9, 12Octadecadienoic acid.

Phytol in $P$. alatum leaf is also found to be effective in different stages of arthritis (Parthipan et al., 2015). Similar results were also observed in the leaves of Lantana camera (Maria et al., 2011), Mimosa pudica (Sridharan et al., 2011) and aerial parts of Flueggea leucopyrus (Sudha et al., 2013). The results demonstrate the reactive oxygen species that promotes substances such as Phytol promising a novel class of pharmaceuticals for the treatment of rheumatoid arthritis and possibly other chronic inflammatory diseases (Ogunlesi et al., 2009).

Vitamin $\mathrm{E}$ has antioxidant and many other medicinal activities (Stampfer et al., 1993; Rimm et al., 1993). Vitamin E is a vital fat-soluble nutrient in the human body. It is essential due to the fact that body cannot manufacture its own vitamin E. So, foods and supplements must provide it (Sen et al., 2006). Epidemiological studies have reported that high vitamin $\mathrm{E}$ intakes are correlated with a reduced risk of cardiovascular diseases, whereas intakes of other dietary antioxidants (such as vitamin $\mathrm{C}$ and $\mathrm{b}$-carotene) are not, suggesting that vitamin E plays specific roles beyond that of its antioxidant function (Stampfer et al., 1993; Rimm et al., 1993). Lipid-soluble antioxidants, such as vitamin $\mathrm{E}$ may protect breast tissue from oxidant damage that may lead to the development of cancer (Baum et al., 1991). It has been proposed that dietary supplementation of vitamin $E$ in excess of dietary requirements may reduce risk of developing breast cancer in women (London et al., 1985). Dietary supplementation of vitamin $E$ is potentially feasible and practical as preventive major measure for breast cancer.

Within a decade, there were several analytical techniques including NMR, TLC, UV, and GC-MS that were powerful tools for separation, identification and structure determination of phytochemicals (Roberts and Xia, 1995). The GC-MS is a method used for screening, identification and quantification 
Table 1. Compounds detected in petroleum ether extract.

\begin{tabular}{|c|c|c|c|}
\hline RT & Chemical name & Peak area & Nature of compound \\
\hline 7.44 & Decane & $(+) 0.39$ & alkanes \\
\hline 8.98 & Naphthalene,decahydro-[4.4.0] decane & $(+) 0.04$ & Aromatic hydrocarbon \\
\hline 10.20 & Undecane & $(+) 0.93$ & alkanes \\
\hline 10.60 & Benzeneethanol & $(+) 0.67$ & Phenol \\
\hline 10.77 & Maltol 4H-pyran-4-one,3-hydroxy-2-methyl & $(+) 2.74$ & Phenol \\
\hline 13.03 & Dodecane & $(+) 1.23$ & alkanes \\
\hline 15.03 & Octane,2,6-di methyl & $(+) 0.16$ & alkanes \\
\hline 21.83 & Benzene, (1-butylhexyl)decane, 5-phenyl-(5-decyl) benzene & $(+) 2.32$ & Phenol \\
\hline 22.40 & Dodecanoic acid & - & Fatty acid \\
\hline 22.90 & 4-Fluoroveratrole ,fluorobenzene,3,4-methoxy & - & Phenol \\
\hline 24.14 & Benzene , (1-butylhebtyl)- undecane, 5-phenyl & $(+) 8.75$ & Phenol \\
\hline 24.36 & Benzen, (1-propyloctyl) - undecane, 4-phenyl- (1- Propyloctyl) benzene & $(+) 4.36$ & Phenol \\
\hline 24.49 & 2-Furanethanol,-.beta.-ethoxy & - & Phenol \\
\hline 24.81 & Benzene, (1-ethylnonyl Undecane, 3-phenyl-3-phenylundecane & $(+) 3.87$ & Phenol \\
\hline 25.62 & Benzen, (1-methyldecyl) -2-phenylundecane, undecane,2-phenyl & $(+) 4.45$ & Phenol \\
\hline 26.22 & Benzene, (1-pentylheptyl)-dodecane, 6-phenyl-6-phenyldodecan & $(+) 2.82$ & Phenol \\
\hline 26.33 & Benzene, (1-butyloctyl)-dodecane,5-phenyl-5-phenyldodecane & $(+) 3.68$ & Phenol \\
\hline 26.56 & Benzene, (1-propylnonyl)-4-phenyldodecane & $(+) 3.81$ & Phenol \\
\hline 27.01 & Benzene, (1-ethyldecyl)-3-phenyldodecane & $(+) 3.26$ & Phenol \\
\hline 27.82 & Benzene, (1-methylundecyl)-dodecane, 2-phenyl- & $(+) 3.50$ & Phenol \\
\hline 28.27 & Benzene, (1-pentyloctyl)- tridecane, 6-phenyl- & $(+) 4.28$ & Phenol \\
\hline 29.25 & 1-Hexadecene & $(+) 0.30$ & Alkanes \\
\hline 29.5 & 9,12,15-Octadecatrienoic acid, & $(+) 0.12$ & Unsaturated fatty acids \\
\hline 30.09 & Farnesol & $(+) 0.08$ & Phenol \\
\hline 30.83 & Hexadecanoic acid & $(+) 0.82$ & Fatty acids \\
\hline 33.17 & 1-Octadecene & $(+) 0.48$ & alkanes \\
\hline 33.72 & Phytol,2-hexadecen-1-ol, 3,7,11,15-tetramethyl & $(+) 7.69$ & Alkanes \\
\hline 34.27 & 9,12,15-Octadecatrienoic acid,linolenic acid & $(+) 2.45$ & Unsaturated fatty acids \\
\hline 34.73 & Ethyl 9, 12, 15-octadecatrienoate & $(+) 0.60$ & Unsaturated fatty acids \\
\hline 36.94 & Tricosane & $(+) 0.18$ & alkanes \\
\hline 40.15 & Pentacosane & $(+) 0.33$ & alkanes \\
\hline 41.67 & Hexacosane & $(+) 0.34$ & alkanes \\
\hline 42.67 & 2H-1-Benzopyran-7-ol,3-(2,4-dimethoxyphenyl) -3,4-dihydro & $(+) 0.23$ & Phenol \\
\hline 44.57 & Octacosane & $(+) 0.65$ & alkanes \\
\hline 45.03 & Squalene & $(+) 3.08$ & triterpene \\
\hline 45.96 & Tetracosane & $(+) 2.61$ & alkanes \\
\hline 46.61 & Oxirane,2,2-dimethyl-3-(3,7,12,16,20)pentamethyl-3,7,11,15,19-heneicosapentaeny & $(+) 0.43$ & alkanes \\
\hline 48.56 & Docosane & (+) 1.00 & alkanes \\
\hline 48.87 & Cholest-5-en-3-ol & $(+) 0.36$ & Phenol \\
\hline 49.08 & Vitamin E & (+) 5.15 & vitamin \\
\hline 50.27 & Ergost-5-en-3-ol & $(+) 0.10$ & Phenol \\
\hline 50.69 & Stigmasterol & $(+) 0.85$ & Steroid \\
\hline 51.49 & Stigmast-5-en-3-ol & $(+) 1.79$ & Steroid \\
\hline
\end{tabular}

of several compounds in plant extracts. Gas chromatography (GC) is used to separate drugs that exist in the sample. The retention time (RT) is an identifying distinctive of a drug. The mass spectrometry (MS) is the detector for the GC.

\section{Materials and methods}

\section{Plant material}

Collection and Identification of the tested plant $A$. maurorum plants were collected from arid land at railway stations in Banha, Qulyubia government, Egypt. The collected plant was identified and authenticated by Botany Dept, Faculty of Science, Benha University, according to (Tackholm, 1974). The aerial part (leaves and stems) were washed with tap water and air-dried. Shoots of $A$. maurorum were oven dried at $50 \cong \mathrm{C}$. After 10 days they reached a constant weight. The plant shoots were grounded to very fine powder in mixer and stored in glass jars until use.

\section{Extraction}

The extraction of dried materials was done by petroleum ether (non-polar) and methanol (have a moderate polarity) using Soxhlet method (Nikhal et al., 2010), and by soaking in water (high polar) at room temp. The extraction was done after 24 hours and the extracts were filtered and concentrated to $5 \mathrm{ml}$ using rotatory evaporator at room temperature.

\section{Analysis method}

The secondary metabolite compounds in three extracts were analyzed by Gas chromatography-mass spectrometry (GCMS) analysis as described by (Wagay and Rothe, 2016). Aglient 6890 gas chromatograph supplied with an Agilent mass spectrometric detector, with a direct capillary interface and fused silica capillary column PAS- $5 \mathrm{~ms}(30 \mathrm{~m} \times 0.32 \mathrm{~mm} \times$ $0.25 \mu \mathrm{l}$ film thickness). Samples were injected under the following conditions. Helium was used as carrier gas at 
Table 2. Compounds detected in methanolic extract.

\begin{tabular}{|c|c|c|c|}
\hline RT & Chemical name & Peak area & Nature of compound \\
\hline 5.95 & Propanedioic acid, dimethyl ester & $(+) 0.78$ & $\begin{array}{l}\text { Fatty acid methyl } \\
\text { ester }\end{array}$ \\
\hline 7.16 & 2,3-Dihydro-3,5-dihydroxy-6-methyl-4h-pyran-4-one & $(+) 1.06$ & Phenol \\
\hline 11.78 & 4H-pyran-4-one,2,3-dihydro-3,5-dihydroxy-6-methyl & $(+) 3.66$ & Phenol \\
\hline 14.28 & 2-Furan- carboxaldehyde,5-(hydroxymethyl) & $(+) 3.33$ & Aldehyde \\
\hline 15.30 & 2-Ethoxyethyl-.beta.-phenylpropionate ,2-ethoxyethyl,3-phenylpropanoate & (+) 1.19 & Phenol \\
\hline 18.30 & (E) -1-(2,3,6-trimethylphenyl)buta-1,3-diene & $(+) 3.59$ & Phenol \\
\hline 19.08 & Acetic acid , (1,2,3,4,5,6,7,8-octahydro -3,8,8-trimethylnaphth-2-yl)methyl ester & $(+) 0.96$ & $\begin{array}{l}\text { Unsaturated fatty } \\
\text { acids }\end{array}$ \\
\hline 19.19 & Ethanone, 1-(2,3-dihydro-1,1-dimethyl-1 h-inden-4-yl) & $(+) 0.60$ & Phenol \\
\hline 20.218 & Benzene , 1-ethyl-3,5-diisopropyl-benzene & (+) 4.54 & Aromatic compound \\
\hline 20.56 & 4-(2,6,6-Trimethylcyclohexa-1,3-dienyl)but-3-en-2-one & $(+) 2.13$ & alkanes \\
\hline 22.40 & Dodecanoic acid & $(+) 0.19$ & Fatty acid \\
\hline 26.83 & Tetradecanoic acid & $(+) 0.93$ & Fatty acid \\
\hline 27.16 & (-)-Loliolide & $(+) 1.06$ & Terpene \\
\hline 30.18 & 9,11-Octedecediynoic acid, 8-hydroxy-methyl ester & (+) 1.24 & Fatty acids \\
\hline 30.83 & Hexadecanoic acid & (+) 4.46 & Fatty acids \\
\hline 30.84 & Mome inositol & $(+) 2.36$ & Phenol \\
\hline 33.50 & 9,12,15-Octadecatrienoic acid, methylester & $(+) 1.30$ & $\begin{array}{l}\text { Fatty acids, methyl } \\
\text { ester }\end{array}$ \\
\hline 33.72 & Phytol,2-hexadecen-1-ol, 3,7,11,15-tetramethyl & $(+) 3.65$ & Alkanes \\
\hline 34.13 & 9,12-Octadecadienoic acid & $(+) 0.88$ & $\begin{array}{l}\text { Unsaturated fatty } \\
\text { acids }\end{array}$ \\
\hline 34.27 & $9,12,15$-Octadecatrienoic acid,linolenic acid & $(+) 3.43$ & $\begin{array}{l}\text { Unsaturated fatty } \\
\text { acids }\end{array}$ \\
\hline 34.61 & Octadecanoic acid & $(+) 1.53$ & $\begin{array}{l}\text { Unsaturated fatty } \\
\text { acids }\end{array}$ \\
\hline 40.32 & Hexadecanoic acid, 2-hydroxy-1-(hydroxymethyl)ethyl ester & $(+) 1.20$ & Fatty acids ethyl ester \\
\hline 40.96 & Bis(2-ethylhexyl) phthalatehalic acid, bis(2-ethylhexyl)ester & (+) 5.58 & Fatty acids ethyl ester \\
\hline 42.67 & 2H-1-Benzopyran-7-ol,3-(2,4-dimethoxyphenyl) -3,4-dihydro & $(+) 1.31$ & Phenol \\
\hline 43.14 & Linolenic acid, 2-hydroxy-1-(hydroxymethyl)ethyl ester & $(+) 2.23$ & $\begin{array}{l}\text { Fatty acids methyl } \\
\text { ester }\end{array}$ \\
\hline 44.42 & 1a,12b-Dihydrobenzo[ b] oxireno- $[9,10]$-phenanthro(3,2-d)thiophene & $(+) 1.57$ & Aromatic compound \\
\hline 49.08 & Vitamin E & $(+) 8.62$ & vitamin \\
\hline 50.26 & (E) -5,10-secocholest-1(10) - en-3,5-dione & $(+) 1.17$ & Phenol \\
\hline 50.69 & Stigmasterol & $(+) 2.62$ & Steroid \\
\hline 51.49 & Stigmast-5-en-3-ol & $(+) 4.21$ & Steroid \\
\hline
\end{tabular}

Table 3. Compounds detected in water extract.

\begin{tabular}{|c|c|c|c|}
\hline RT & Chemical name & Peak area & Nature of compound \\
\hline 4.00 & 2,3-Butanediol,2,3-butanediol & $(+) 3.14$ & Phenol \\
\hline 4.13 & 1,3-Butanadiol,1,3-butylene glycol & (+) 17.40 & Phenol \\
\hline 5.65 & Oxime-,methoxy-phenyl,methyl -hydroxybenzenecarboximidoate & (+) 1.05 & Phenol \\
\hline 14.85 & 1,2-Benzenediol, 3-methoxy-pyrocatechol, 3-methoxy & (+) 1.36 & Phenol \\
\hline 16.05 & 1,2-Ethanediol,1-phenyl- styrene glycol & $(+) 1.25$ & Phenol \\
\hline 17.48 & Erythritol & $(+) 0.40$ & Terpene \\
\hline 18.30 & (E) -1-(2,3,6-trimethylphenyl)buta-1,3-diene & $(+) 0.70$ & Phenol \\
\hline 19.25 & Phenol, 4-(methoxymethyl) & $(+) 1.23$ & Phenol \\
\hline 20.18 & Ledol & (+) 4.01 & TERPEN \\
\hline 20.82 & 2,3-Dimethylpenzene-1,4-dicarbonitrile & (+) 20.26 & Phenol \\
\hline 22.90 & 4-Fluoroveratrole ,fluorobenzene,3,4-methoxy & (+) 19.52 & Phenol \\
\hline 24.49 & 2-Furanethanol,-.beta.-ethoxy & $(+) 2.08$ & Phenol \\
\hline 25.61 & Tetradecanoic acid, methyl ester & $(+) 0.51$ & Fatty acid \\
\hline 27.29 & (3,4-Dihydroxyphenyl) hexylamine & (+) 1.39 & Phenol \\
\hline 28.82 & Oxacyclododeca-6,9-dien-2-one,7-methyl & (+) 1.32 & Alkanes \\
\hline 30.83 & Hexadecanoic acid & $(+) 0.87$ & Fatty acids \\
\hline 50.99 & 2-p-Nitrophenyl-1,3,4-oxadiazol-5-one & (+) 2.29 & Phenol \\
\hline
\end{tabular}


Table 4. Anticancer compounds in the three extracts.

\begin{tabular}{|c|c|c|c|c|}
\hline \multirow{2}{*}{ Name of compound } & \multicolumn{3}{|l|}{ Peak area } & \multirow{2}{*}{$\begin{array}{l}\text { Nature of } \\
\text { compound }\end{array}$} \\
\hline & Petroleum ether & Methanol & Water & \\
\hline Vitamin E & $+(5.15)$ & $+(8.62)$ & - & Vitamin \\
\hline Hexadecanoic acid & $+(0.82)$ & $+(4.46)$ & $+(0.87)$ & Fatty acid \\
\hline Stigmast-5-en-3-ol & $+(1.79)$ & $+(4.21)$ & - & Steroid \\
\hline Phytol,2-hexadecen-1-ol, 3,7,11,15-tetramethyl & $+(7.69)$ & $+(3.65)$ & - & Terpinoid \\
\hline Squalene & $+(3.08)$ & - & - & Triterpene \\
\hline Hexadecanoic acid , 2-hydroxy-1-(hydroxymethyl) ethyl ester & - & $+(1.20)$ & - & $\begin{array}{l}\text { Fatty acid ethyl } \\
\text { ester }\end{array}$ \\
\hline Oxime-,methoxy-phenyl,methyl N-hydroxybenzenecarboximidoate & - & - & $+(1.05)$ & Phenol \\
\hline Ergost-5-en-3-ol & $+(0.10)$ & - & - & Phenol \\
\hline 9,12-Octadecadienoic acid & - & $+(0.88)$ & - & $\begin{array}{l}\text { Unsaturated } \\
\text { fatty acid }\end{array}$ \\
\hline Farnesol & $+(0.08)$ & - & - & Phenol \\
\hline
\end{tabular}
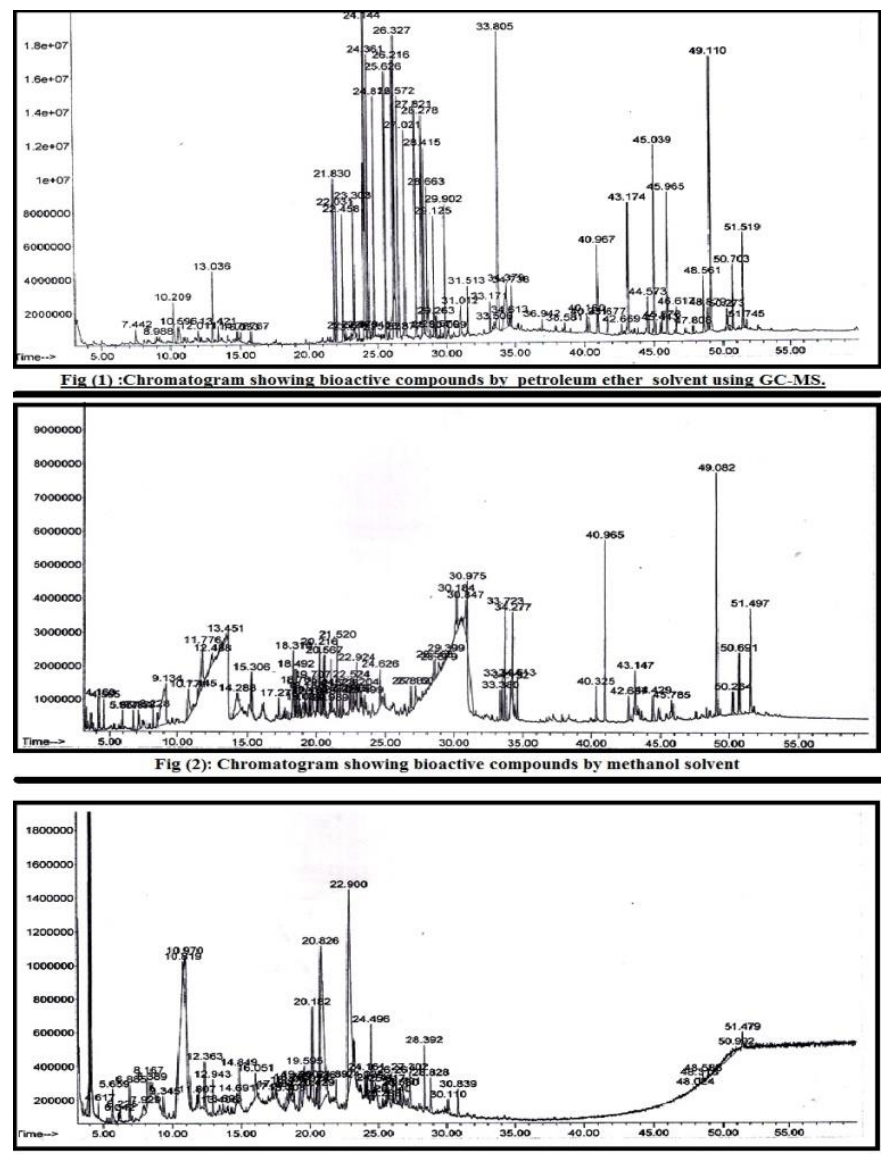

Fig (3): Chromatogram showing bioactive compounds by aqueous solvent using GC-MS.

The electron multiplier voltage (EM voltage) was maintained at $1650 \mathrm{~V}$ above auto tune. The instrument was manually tuned using perfluorotriputyl amine (PFTBA). The GC temperature program was started at $60^{\circ} \mathrm{C}(2 \mathrm{~min})$ then elevated to $300^{\circ} \mathrm{C}$ at rate of $5^{\circ} \mathrm{C} / \mathrm{min}$. The injector temperature was set to $280{ }^{\circ} \mathrm{C}$. Wiley and Wiley Nist mass spectral data base was used in the identification of the separated peaks. The previous analyses were done at the central pesticides laboratory.

\section{Conclusion}

This study provides information on $A$. maurorum and its natural products which have many biological activities. It is documented that $A$. maurorum is rich in anticancer compounds and has great potential to be developed into anticancer drug.

\section{References}

Ahmad N, Shinwari ZK, Hussain J, Perveen R (2015) Phytochemicals antibacterial and antioxidative investigations of Alhagi maurorum medik. Pak J Bot. 47(1): 121-4.

Al-Jaber NA, Awaad AS and Moses JE (2011) Review on some antioxidant plants growing in Arab world. J Saudi Chem Soc. 15: 293-307. 
Al-Snafi AE (2015) Alhagi maurorum as a potential medicinal herb. an overview. Inte J Pharm Rev Res. 5(2).

Arunkumar S, Muthuselvam M (2009) Analysis of phytochemical constituents and antimicrobial activities of Aloe vera $\mathrm{L}$. against clinical pathogens. World J Agric Sci. 5(5):572-576.

Asmeda AA (2013) Ecology and phytochemistry of some taxa of family labiatae (lamiaceae). M SC thesis, Fac Sci Mans univ Egy P 145.

Awaad AS, El-Meligy RM, Qenawy SA, Atta AH and Soliman GA (2011) Antiinflammatory, antinociceptive and antipyretic effects of some desert plants. J Saudi Chem Soc. 15: 367-73.

Awad AB, Chen YC, Fink CS and Hennessey T (1996) Betasitosterol inhibits HT-29 human colon cancer cell growth and alters membrane lipids. Anticancer Res. 16: 2797-804.

Baum M, Ziv Y, Colletta A (1991) Prospects for the chemoprevention of breast cancer. Br Med Bull. 47: 493503.

Behari M, Gupt SC (1980) The isolation and biogenesis of 24alkylsterols in Alhagi pseudoalhagi. Acta Cienc Ind Chem. 6: 207-208.

Behbahani M (2014) Evaluation of in vitro anticancer activity of Ocimum Basilicum, Alhagi Maurorum, Calendula Officinalis and their parasite Cuscuta Campestris. Plos One. 9(12):e116049.

Belanger JT (1998) Perillyl alcohol applications in oncology Altern Med Rev. 3(6) :448-57.

Bodoprost J, Rosemeyer H (2007) Analysis of phenacylester derivatives fatty acids from human skin surface sebum by reversed-phase HPTLC. Int J Mol Sci. 8 : 11-24.

Crowell PL (1999) Prevention and therapy of cancer by dietary monoterpenes. J Nutr. 129.

De Oliveira GG, Pereira J, Bastos ISFR and Lopes NP (2014) Phytochemical investigation of chloroform extract from root, stem and leaf of Adenocalymma imperatoris maximilianii (Wawra) L.G. Lohmam (Bignoniaceae). Int J Pharm Bio Sci. 5(3):70-78.

De Stefani E, Boffetta P, Ronco AL, Brennan P, DeneoPellegrini H , Carzoglio JC and Mendilaharsu M (2000) Plant sterols and risk of stomach cancer a case-control study in Uruguay. Nutr Cancer. 37: 140-4.

Devi PM, Nagarajan AJM, Christina R, Meera N, Merlin J (2009) GC-MS analysis of Euphorbia longan leaves. Int J Pharm Res Develop. 32 (8):1-4.

Duke JA (2007) Duke's handbook of medicinal plants of the bible. USA: CRC Press.

Ekade PP, Manik SR (2014) Investigations on secondary metabolites in different parts of Radermachera xylocarpa using GC-MS. J Pharmacog Phytochem. 2(6):39-47.

Gabay O, Sanchez C, Salvat C, Chevy F, Breton M, Nourissat G (2010) Stigmasterol a phytosterol with potential antiosteoarthr properties. Osteo Cart. 18(1):106-116.

Hamed A, Perrone A, Mahalel U, Oleszek W, Stochmal A, Piacente S (2012) Oleanane glycosides from the roots of Alhagi maurorum. Phytochem Lett. 5:782-787.

Harada H, Yamashita U, Kurihara H, Fukushi E, Kawabata J, Kamei Y (2002) Antitumor activity of palmitic acid found as a selective cytotoxic substance in a marine red alga. Antican Res. 22: 2587-90.

Hassanein AM, Mazen MA (2010) Adventitious bud formation in Alhagi graecorum. Plant Cell Tiss Org Cult. (65): 31-35.
Hema R, Kumaravel S, Alagusundaram (2011) GC/MS determination of bioactive components of Murraya koenigii. J Amer Sci. 7(1):80-83.

Himaja M and Moonjit D (2014) Phytochemical screening, GC-MS analysis and biological activities of Ipomoea eriocarpa leaf extracts. Int J Pharm Sci. 6(4):592-594.

Hsouna $A B$, Trigie $M$, Mansour RB, Jarraya RM, Damak $M$, and Jaoua $S$ (2011) Chemical composition, cytotoxicity effect and antimicrobial activity of Ceratonia silisqua essential oil with preservative effects against listeria inoculated in minced beef meat. Int J Food Micro. 148(1): 66-72.

Huang JG, Zhou L, Xu HH and Li WO (2009) Insecticidal and cytotoxic activities of extracts of Cacalia tangutica and its two active ingredients against Musca domestica and Aedes albopictus. J Econ Entom. 102 (4): 1444-1447.

Jabra-Rizk MA, Meiller TF, James CE and Shirtliff ME (2006) Effect of farnesol on Staphylococcus aureus biofilm formation and antimicrobial susceptibility. Anti A Chem. 50: 1463-1469.

Jiang $Q$, Chisten S, Shigenaga MK and Ames BN (2001) vtocopherol, the major form of vitamin $E$ in the US diet, deserves more attention. Am J Clin Nutr. 74: 714-22.

Kalhoro MA, Kapadia Z and Badar Y (1997) Physicochemical studies of indigenous medicinal plants. Bangl J Sci Ind Res. 32: 418-421.

Karuppasamy B, Antony N and Veerabahu RM (2012) GC-MS analysis of Polycarpaea corymbosa (L.) Lam whole plant. Asi Pac J Trop Bio. 1289-1292.

Kuppuswamy KM, Bhavana J and Sumathy A (2013) GC-MS analysis of chloroform extract of Croton bonplandianum. Int J Pharm Bio Sci. 4(4):613-617.

London RS, Murphy L and Kitlowski KE (1985) Breast cancer prevention by supplemental vitamin E. J Am Coll Nutr. 4: 559-564.

Mangunwidjaja DS, Kardono SR, Iswantini LBSD (2006) Gas chromatography and gas chromatography-mass spectrometry analysis of Indonesian Croton tiglium seeds. J Appl Sci. 6:1576-1580.

Marashdah MS, Al-Hazimi HM (2010) Pharmacological activity of ethanolic extract of Alhagi maurorum roots. Arab J Chem. 3(1):39-42.

Maria Jancy Rani P, Kannan PSM, Kuma SI (2011) GC-MS analysis of Lantana camara L. leaves. Int J Pharmaceut Res Dvelop. 2(11):63- 66.

McCann SE, Freudenheim JL, Marshall JR, Graham S (2003) Risk of human ovarian cancer is related to dietary intake of selected nutrients, phytochemicals and food groups. J Nutr. 133: 1937-42.

Mendilaharsu M, Stefani ED, Deneo-Pellegrini H, Carzoglio J and Ronco A (1998) Phytosterols and risk of lung cancer. A case-control study in Uruguay. Lung Cancer. 21: 37-45.

Nikhal SB, Dambe PA, Ghongade DB and Goupale DC (2010) Hydroalcoholic extraction of Mangifera indica (leaves) by soxhletion. Inte J Pharm Sci. 2(1):30-32.

Ogunlesi M, Okiei W, Ofor E, Obote AE (2009) Analysis of the essential oil from the dried leaves of Euphorbia hirta Linn (Euphorbiaceae) a potential medication for asthma. Afr J Bio Tech. 8:7042-7050.

Parasuraman S, Raveendran R, Madhavrao C (2009) GC-MS analysis of leaf extracts of Cleistanthus collinus (Euphorbiaceae). Int J Ph Sci. 1(2):284-286. 
Parthipan B, Suky MGT, Mohan VR (2015) GC-MS Analysis of phytocomponents in Pleiospermium alatum Swingle (Rutaceae) . J Pharmaco Phyto. 4(1): 216-222.

Pietro Z, Maurizio S, Maurizio B, Antonella M, Sergio R, Carmen F, Felice S (2010) Essential oil composition of stems and fruits of Caralluma europaea (Apocynaceae). Mol. 15: 627-638.

Praveen kumar P, Kumaravel S, Lalitha C (2010) Screening of antioxidant activity, total phenolics and GC-MS study of Vitex negundo. Afr J Biochem Res. 4(7):191195.

Rao CV, Newmark HL, Reddy BS (1998) Chemo preventive effect of squalene on colon cancer. Carcino. $19: 287-90$

Revathi P, Parimelazhghan T (2010) Traditional knowledge on medicinal plants used by Irula tribe of Hasanur hills Erode District. Ta Nadu Ind Eth Leaf. 14:136-60.

Rimm ER, Stampfer MJ, Ascherio A, Giovannucci E, Colditz GA, and Willett WC (1993) Vitamin E consumption and the risk of coronary heart disease in men. $N$ Engl J Med. 328:1450-1456.

Rioja A, Pizzey AR, Marson CM, Thomas NS (2000) Preferential induction of apoptosis of leukaemic cells by farnesol. FEBS Letter. 467(2-3)291-5.

Roberts JKM and Xia JH (1995) High- resolution NMR methods for study of higher plants. Meth Cell Biol. 49:245258.

Samejo MQ, Memon S, Khan KM (2012) Chemical composition of essential oils from Alhagi maurorum. Chem Nat Comp. 48(5): 898- 900.

Scalbert A, Williamson G (2000) Dietary intake and bioavailability of polyphenols. J Nutri. 130: 2073S-85S.

Semighini CP, Hornby JM, Dumitru R, Nickerson KW and Harris SD (2006) Farnesol-induced apoptosis in Aspergillus nidulans reveals a possible mechanism for antagonistic interactions between fungi. Mol Micro. 59:753-764.

Sen CK, Khanna S and Roy S (2006) Tocotrienols vitamin E beyond tocopherols. Li Sci. 78(18): 2088- 2098.

Sermakkani M and Thangapandian V (2012) GC-MS analysis of Cassia italica leaf Methanol Extract. Asi J Pharmaceut I Clin Rese. 5(2):90-94.

Shubhangi NI (2016) Phytochemical analysis of leaf extract of Ocimum americanum L. (Lamiaceae) by GCMS method. World Sci News. 37: 76-87.

Sianipar NF, Purnamaningsih R and Rosaria (2016) Bioactive compounds of fourth generation gamma-irradiated Typhonium flagelliforme Lodd mutants based on gas chromatography-mass spectrometry. IOP Conf. Series: Ear and Envir Sci. 41.
Siddiq Ibraham A, Ahmad Bustamam A, Manal Mohammed E, Syam MI , Mohamed M Yousif, Abdelbasit A, Alhaj NA (2009) GC-MS determination of bioactive components and antibacterial properties of Goniothalamus umbrosus extracts. Afr J Biotech; 8(14):3336-3340.

Sridharan S, Meenaa V, Kavitha V, John Nayagam AA (2011) GC-MS study and phytochemical profiling of Mimosa pudica Linn. J Pharm Res. 4(3):741-742.

Stampfer M, Hennekens C, Manson J, Colditz G, Rosner B and Willett W (1993) Vitamin E consumption and the risk of coronary disease in women. N Engl J Med. 328:14441449.

Sudha T, Chidambarampillai S, Mohan VR ( 2013) GC-MS analysis of bioactive components of aerial parts of Fluggea leucopyrus Willd. (Euphorbiaceae). J Appl Pharmaceut Sci. 3(05):126-130.

Sulaiman GM (2013) Antimicrobial and cytotoxic activities of methanol extract of Alhagi maurorum. Afr J Microbiol Res. 7(16):1548-57.

Sujatha S, Anand S, Sangeetha KN, Shilpa K, Lakshmi J, Balakrishnan A, Lakshmi BS (2010) Biological evaluation of (3ß)-stigmast-5-en-3-ol as potent anti-diabetec agent in regulating glucose transport using in vitro model. Int J Diab Mellit. 2: 101-9.

Tackholm V (1974) Students flora of Egypt, seconded. Cai Univ Press. pp:300.

Verma S, Mohanta T, Revathy T, Suthindhiran K, Jayasri MA (2013) Phytochemical and pharmacological evaluation of selected plants. Am J Biochem Biotechnol. 9(3): 291-9.

Wagay NA and Rothe SP (2016) Investigations on secondary metabolites of Alhagi pseudalhagi leaves using GC-MS Wagay. Pharm Phytochem. 5(5): 114-118.

Yazlovitskaya EM and Melnykovych G (1995) Selective farnesol toxicity and translocation of protein kinase $\mathrm{C}$ in neoplastic HeLa-S3K and non-neoplastic CF-3 cells. Can Lett. 88(2): 179-83.

Yu F, Lian X, Guo H, McGuire P, Li R, Wang R, Yu F (2005) Isolation and characterzation of methyl esters and derivatives from Euphorbia kansui (Euphorbiaceae) and their inhibitory effects on the human SGC-7901 cells J. Pharm. Pharmaceut Sci. 8(3) :528-35.

Zawistowski J (2010) Tangible health benefits of phytosterol. Funct Food In J. pp:362-372. 